\title{
PENGARUH KEBIJAKAN DIVIDEN, LIKUIDITAS, TANGIBILITY, ASSET TURNOVER, DAN COMPANY GROWTH TERHADAP STRUKTUR MODAL
}

\author{
${ }^{1}$ Mirnawati \\ ${ }^{2}$ Anita Wijayanti \\ ${ }^{3}$ Purnama Siddi \\ 1,2,3 Program Studi Akuntansi, Fakultas Ekonomi \\ Universitas Islam Batik Surakarta \\ mirnawatiratulolly@gmail.com
}

\begin{abstract}
Abstrak
Struktur modal adalah perbandingan antara hutang (modal asing) dengan modal sendiri (ekuitas). Terdapat beberapa faktor yang mempengaruhi struktur modal diantaranya seperti kebijakan dividen, likuiditas, tangibility, asset turnover dan company growth. Penelitian ini bertujuan untuk mengetahui pengaruh kebijakan dividen, likuiditas, tangibility, asset turnover dan company growth terhadap struktur modal. Dalam penelitian ini, metode pengambilan sampel dilakukan dengan menggunakan Purposive sampling dan diperoleh sebanyak 14 perusahaan sektor industri barang konsumsi yang terdaftar di BEI selama tahun 2015-2018. Dengan demikian jumlah data yang diamati dalam penelitian ini berjumlah 56 data. Data pada penelitian ini dianalisis menggunakan Software Statistical Package for Social Sciences (SPSS) 22 dengan metode analisis regresi linear berganda. Hasil penelitian ini menunjukan bahwa likuiditas dan asset turnover berpengaruh terhadap struktur modal sedangkan kebijkan dividen, tangibility dan company growth tidak berpengaruh terhadap struktur modal.
\end{abstract}

\section{Kata Kunci : DPS, Likuiditas, Tangibility, Turnover, Growth}

\begin{abstract}
Capital structure is the ratio between debt (foreign capital) and own capital (equity). There are several factors that affect capital structure such as dividend policy, liquidity, tangibility, asset turnover and company growth. This study aims to determine the effect of dividend policy, liquidity, tangibility, asset turnover and company growth on capital structure. In this study, the sampling method was carried out using purposive sampling and obtained as many as 14 companies in the consumer goods industry sector which were listed on the Indonesia Stock Exchange during 2015-2018. Thus the amount of data observed in this study amounted to 56 data. Data in this study were analyzed using Statistical Package for Social Sciences (SPSS) 22 with multiple linear regression analysis methods. The results of this study indicate that liquidity and asset turnover affect the capital structure while the dividend policy, tangibility and company growth do not affect the capital structure.
\end{abstract}

Keyword : DPS, Likuidity, Tangibility, Turnover, Growth

\section{PENDAHULUAN}

Perkembangan perusahaan dalam upaya mengantisipasi persaingan semakin ketat, ini akan selau dilakukan oleh perusahaan baik yang berskala kecil maupun besar. Upaya ini untuk mempertahankan dan memajukan kehidupan perusahannya. Pada dasarnya tujuan dari suatu perusahaan adalah untuk memaksimalkan kesejahteraan pemilik melalui peningkatan nilai perusahaan. Hal penting yang perlu diperhatikan oleh perusahaan agar tujuan tersebut dapat tercapai adalah aspek pendanaan atau permodalan. Adanya kekurangan pendanaan akan megakibatkan terhambatnya kegiatan perusahaan seperti pembelian bahan baku, distribusi, dan lain-lain. Sehingga perusahaan memerlukan tambahan dana yang tidak sedikit (Widayanti, 2016) . 
Para calon investor akan melihat struktur modal sebagai pertimbangan utama dalam menginvestasi dananya di suatu perusahaan, terkait dengan risiko dan pendapatan yang diharapkan para calon investor (Nurmadi, 2013). Manajer keuangan suatu perusahaan harus mampu menyusun keputusan pendanaan yang tepat sehingga tercipta struktur modal optimal bagi perusahaan. (Houston, 2011) yang menyatakan bahwa strutur modal yang mengoptimalkan keseimbangan pengembalian dan risiko sehingga harga saham perusahaan menjadi maksimum. Semakin tinggi penggunaan utang maka akan semakin besar risiko yang dihadapi perusahaan tetapi tingkat pengembalian yang diharapkan perusahaan juga semakin besar. Harga saham perusahaan cenderung menurun jika risiko yang dihadapi perusahaan semakin tinggi akibat dari penggunaan utang, tetapi harga saham perusahaan akan naik jika tingkat pengembalian yang diharapkan perusahaan semakin besar. Struktur modal adalah perbandingan antara hutang (modal asing) dengan modal sendiri (ekuitas) (Halim, 2015:81). Secara langsung keputusan struktur modal akan mempengaruhi kondisi dan nilai perusahaan serta menentukan kemampuan perusahaan untuk tetap bertahan dan berkembang. Faktor-faktor yang mempengaruhi struktur modal yaitu kebijakan dividen, likuiditas, tangibility, asset turnover, dan company growth.

Riyanto (2011) kebijakan dividen adalah kebijakan yang bersangkutan dengan penentuan pembagian pendapatan (earning) antara pengguna pendapatan untuk dibayarkan kepada para pemegang saham sebagai dividen atau untuk digunakan dalam perusahaan, yang berarti pendapatan tersebut harus ditanam didalam perusahaan. Dividen merupakan salah satu tujuan investor dalam melakukan investasi saham. Sehingga apabila besarnya dividen tidak sesuai dengan harapan investor maka akan cenderung tidak membali suatu saham atau menjual saham tersebut apabila telah memilikinya.

Likuiditas menurut (Sartono, 2012:275)yang merupakan kemampuan perusahaan untuk memenuhi kewajiban finansial yang bersifat jangka pendek dengan tepat waktu. Manfaat perhitungan rasio likuiditas terkait antisipasi keperluan dana utamanya untuk kebutuhan terdesak. Suatu perusahaan yang memiliki tingkat likuiditas yang tinggi akan cenderung mengurangi penggunaan hutang. Perusahaan yang dapat mengembalikan hutang-hutangnya akan mendapat kepercayaan dari kreditur untuk menerbitkan hutang dalam jumlah besar. Apabila perusahaan lebih memilih struktur modal dengan sumber dana yang lebih dominan, maka akan memperkecil biaya modal. Akan tetapi tingkat pengembalian keuntungan yang diharapkan para pemegang saham juga akan kecil karena laba ditahan sebagian besar digunakan untk membiayai serangkaian proyek investasi perusahaan.

Tangibility menurut (Ramadhan, 2010) merupakan perbandingan jumlah asset tetap terhadap terhadap total keseluruhan aset yang ada. Aset tersebut akan digunakan sebagai jaminan yang diminta oleh kreditor atas pinjaman yang dilakukan perusahaan. Semakin besar struktur aset maka semakin besar penggunan utang pada struktur modal. Menurut (Houston, 2011), perusahaan yang asetnya memamadai untuk digunakan sebagai jaminan pinjaman cenderung akan cukup banyak menggunkan hutang. Peningkatan jumlah tangibility perusahaan akan memberikan pengaruh pada keputusan struktur modal perusahaan. Perusahaan yang mempunyai total aktiva berwujud (tangible asset) dalam jumlah yang besar akan memiliki kesempatan lebih besar untuk mendapatkan pinjaman utang.

Aset turnover menurut (Kasmir, 2015) merupakan rasio yang digunakan untuk mengukur perputaran semua aktiva yang dimilki perusahaan dioperasionalkan dalam mendukung penjualan perusahaan. Semakin tinggi rasio ini berarti semakin tinggi produktivitas penggunaan seluruh asset perusahaan. Semakin besar nilai asset turnover berarti semakin baik karena hal tersebut menunjukan adanya perputaran aktiva secara efisien dalam menghasilkan laba sehingga dapat membuat volume penjualan meningkat.

Company growth menurut (Lina, 2010) berpendapat bahwa pertumbuhan perusahaan pada dasarnya menggambarkan bagaimana perusahaan menginvestasikan dana yang ia miliki untuk kegiatan operasi dan investasi. Peningkatan jumlah aset, baik aset lancar maupun aset jangka panjang membutuhkan dana, dengan alternatif pendanaan internal 
atau dengan pendanaan eksternal. Semakin besar kebutuhan untuk pembiayaan mendatang maka semakin besar keinginan perusahaan menahan laba.

Penelitian ini bertujuan untuk mengetahui kebijakan dividen, likuiditas, tangibiliti, asset turnover, dan compani growth terhadap struktur modal.

\section{TINJAUAN LITERATUR}

\section{Teori Agensi (Agency Theory)}

Agency Theory menurut (Fahmi, 2012) menyatakan bahwa manajemen merupakan agen dari pemegang saham, sebagai pemilik perusahaan. Para pemegang saham berharap agen akan bertindak atas kepentingan mereka sehingga kontributor modal akan dipengaruhi oleh bauran pendanaan perusahaan. Manajer atau agen dalam menjalankan perusahaan mempunyai kewajiban untuk mengelola perusahaan sebagaimana diamanahkan oleh pemilik atau para pemegang saham (principal).

\section{Struktur Modal}

Menurut (Budiarso, 2014) struktur modal (capital structure) penggunaan pada perbedaan pilihan dalam membiayai assetnya, yang brupa utang, ekuitas dan sumber keuangan lainnya. Struktur modal dapat dihitung dengan menggunakan rumus DER (Debt Equity Ratio) :

\section{Kebijakan Dividen}

$$
D E R=\frac{\text { Total Hutang }}{\text { Total Ekuitas }}
$$

Riyanto (2011) kebijakan dividen adalah kebijakan yang bersangkutan dengan penentuan pembagian pendapatan (earning) antara pengguna pendapatan untuk dibayarkan kepada para pemegang saham sebagai dividen atau untuk digunakan dalam perusahaan, yang berarti pendapatan tersebut harus ditanam didalam perusahaan. Kebijakan dividen dapat diukur dengan menggunakan rumus DPS (Dividen Payout Ratio):

\section{Likuiditas}

$$
D P R=\frac{\text { Total Dviden }}{\text { Laba Bersih }}
$$

Likuiditas merupakan rasio yang digunakan untuk mengukur kemampuan perusahaan didalam membayar hutang jangka pendek yang telah jatuh tempo (Wiagustini 2014). (Hani, 2015) likuiditas adalah kemampuan suatu perusahaan dalam memenuhi semua kewajiban keuangan yang segera dapat dicairkan atau yang sudah jatuh tempo. Likuiditas dapat diuku menggunakan rumus CR( Current Rasio) :

$$
\text { Likuiditas }=\frac{\text { Aktiva Lancar }}{\text { Hutang Lancar }}
$$

\section{Tangibility}

Menurut (Setiawan, 2016) adalah aktiva tetap perusahaan. Aset tetap berwujud yang diperoleh dalam bentuk siap pakai atau dibangun lebih dahulu yang digunakan dalam operasi perusahaan. Menurut Brigham dan Houstan (2011), perusahaan yang asetnya memamadai untuk digunakan sebagai jaminan pinjaman cenderung akan cukup banyak menggunakan hutang. Tangibility dapat diukur mengunakan rumus :

$$
\text { Tangibility }=\frac{\text { Fixed Asset }}{\text { Total Asset }}
$$




\section{Asset Turnover}

Asset turnover merupakan rasio yang menggunakan pengukuran dari seluruh aktiva yang dimilki perusahaan serta jumlah penjualan yang diperoleh dari setiap jumlah aktiva. Asset turnover merupakan rasio yang menggambarkan penggunaan keseluruhan aktiva secara efisiensi dalam menghasilkan volume penjualan tertentu (Syamsudin, 2009). Asset turnover dapat dikur menggunakan rumus:

$$
\text { Asset Turnover }=\frac{\text { Net Sales }}{\text { Total Asset }}
$$

\section{Company Growth}

Company growth menurut (Lina, 2010) berpendapat bahwa pertumbuhan perusahaan pada dasarnya menggambarkan bagaimana perusahaan menginvestasikan dana yang ia miliki untuk kegiatan operasi dan investasi. Peningkatan jumlah aset, baik aset lancar maupun aset jangka panjang membutuhkan dana, dengan alternatif pendanaan internal atau dengan pendanaan eksternal Perusahaan yang tumbuh memerlukan banyak dana didalam menjalankan aktivitas perusahaan.

$$
\text { Company growth }=\frac{\text { Total Asset } t-\text { Total Asset } t-1}{\text { Total Asset } t-1}
$$

\section{Hipotesis}

\section{Pengaruh Kebijakan Dividen terhadap Struktur Modal}

Perusahaan dengan pembagian dividen yang rendah kepada pemegang saham maka cadangan modal sendiri yang dimilki perusahaan dalam bentuk laba ditahan akan semakin besar, sehingga perusahaan menggunakan dana internalnya dan struktur modal perusahaan menjadi lebih rendah. Sebaliknya, jika tingkat pembagia dividen kepada pemegang saham lebih tinggi maka cadangan modal sendiri yang dimilki perusahaan dalam bentuk laba ditahan akan semakin rendah, sehingga perusahaan menggunakan dana eksternal (utang) dan struktur modal perusahaan menjadi tinggi. Hasil penelitian ini didukung oleh penlitian terdahalu yang dilakukan oleh oleh (Ardhianto, 2014), ( Ni Putu, 2015), (Triani, 2014), (Mohammad, 2015), (Eviana, 2015) dan (Nainggolon, 2017) yang menyatakan kebijakan dividen berpengaruh terhadaap struktur modal.

H1 : Kebijakan Dividen berpengaruh terhadap Struktur Modal

\section{Pengaruh Likuiditas terhadap Struktur Modal}

Posisi perusahaan yang semakin likuid juga menjadi dasar persetujuan melakukan persetujuan investasi maupun ekspansi ke bisnis lain yang dianggap menguntungkan. Perusahaan yang memiliki struktur aktiva tetap yang tinggi maka struktur modalnya semakin tinggi karena bertambahnya peggunaan utang. Hasil penelitian (Sheikh, Nadeem, \& Zongjun, 2011), (Pattweekongka, 2014), (Ananto, 2015), (Luh Putu Widayanti, 2016) (Dewiningrat \& Mustanda, 2018), (Primantara, 2016),.yang menyatakan bahwa likuiditas bepengaruh terhadap struktur modal.

H2 : Likuiditas berpengaruh terhadap Struktur Modal.

\section{Pengaruh tangibility terhadap Struktur Modal}

semakin besar proporsi asset tangibility perusahaan, maka kreditur akan mudah memberi dalam memenuhi kewajiban dalam waktu dekat sesegera mungkin yang semakin meningkat tentunya akan berdampak pada citra perusahaan yang membaik berimbas pada pinjaman, sehingga tingkat hutang perusahaan menjadi besar. Taksiran kemampuan ketertarikan investor sehingga kenaikan nilai yang tercermin pada harga saham juga merangkak naik. Hasil penelitian (Puspitasari, 2016), (Arief et al, 2016), (Setiawan, 2016), (Mulyani, 2017), (Yunita \& Aji, 2018) dan (Ghifaari, 2018) yang menyatakan bahwa tangibility berpengaruh terhadap struktur modal.

H3 : Tangibility berpengaruh terhadap Struktur Modal 


\section{Pengaruh asset turnover terhadap Struktur Modal}

Semakin tinggi asset turnover menunjukan semakin efektif pihak manajemen dalam mengelola aset perusahaan untuk menjalankan kegiatan perusahaan. Semakin tinggi nilai perputaran aset mencerminkn semakin tinggi pula nilai penjualan terhadap struktur modal. Hasil peneliti (Gunawan, 2011), (Sabir, 2012), (Meidiyustianti, 2016), ( Wardhana, 2016), Wiawatankantang dan Santi ( 2017) dan (Ghifaari, 2018) menyatakan bahwa asset turnover berpengaruh terhadap struktur modal.

H4 : Asset turnover berpengaruh terhadap Struktur Modal

\section{Pengaruh company growth terhadap Struktur Modal}

Dalam hubungannya dengan leverage, perusahaan dengan tingkat pertumbuhan yang tinggi sebaiknya menggunakan ekuitas sebagai sumber pembiayaannya agar tidak terjadi biaya keagenan (agency cost) antara pemegang saham dengan manajemen perusahaan. Sebaliknya, perusahaan dengan tingkat pertumbuhan yang rendah sebaiknya menggunakan hutang sebagai sumber pembiayaannya karena penggunaan hutang akan mengharuskan perusahaan tersebut membayar bunga secara teratur. Peneliti (Putra, 2012), (Arini, 2013), (Khairy, 2016), (Pratheepan, 2016), (Sahabuddin, 2017), (Astuti, 2018) dan (Yunita \& Aji, 2018) menunjukan pertumbuhan perusahaan berpengaruh terhadap struktur modal.

H5 :Company Growth berpengaruh terhadap Struktur Modal

\section{METODOLOGI PENAEITIAN}

Metodologi menggunakan metode kuantitatif dengan pendekatan kausal komparatif yang berarti penelitian yang menunjukan hubungan variabel dependen dengan variabel indepen. Variabel pada penelitian ini adalah : (1) Dependen yaitu Struktur Modal , (2) Indepvenden yaitu kebijakan dividen, likuiditas, tangibility, asset turnover dan company growth. Sedangkan data pada penelitian ini adalah data sekunder. Menurut Sugiyono (2009), data sekunder merupakan data yang menunjukan suatu informasi langsung kepada penggabung penelitian. maka data sekunder penelitian ini berupa Laporan keuangan perusahaan Sektor industri barang konsumsi yang terdaftar dari situs di BEI www.idx.ac.id tahun 2015-2018.

Populasi pada penelitian ini sebanyak 52 perusahaan. Sampel dalam penelitian ini berupa perusahaan sub-sektor makanan dan minuman yang terindeks di BEI tahun 20152018 yang memenuhi kriteria ,berdasarkan purposive sampling terdapat 14 perusahaan yang memenuhi kriteria untuk dijadikan sampel penelitian.

Metode analisis yang digunakan adalah regresi linear berganda dengan menggunakan angka-agka dan perhitungan statistik dengan software spss 22 dengan uji asumsi klasik dan Uji Regresi Berganda

\section{HASIL DAN PEMBAHASAN}

Tabel 1

Hasil Uji Normalitas Kolmogrov - Smirnov

\begin{tabular}{|c|c|c|c|}
\hline & Sig & Standar & Keterangan \\
\hline $\begin{array}{l}\text { Asymp.Sig. } \\
\text { (2-tailed) }\end{array}$ & 0,202 & $>0,05$ & Terdistribusi Normal \\
\hline
\end{tabular}

Berdasarkan tabel 1 dapat diketahui bahwa nilai signifikansi Kolmogrov Smirnov (K-S) adalah 0,202 , artinya bahwa nilai tersebut lebih besar dari 0,05 yang berarti bahwa data terdistribusi normal. 
Tabel 2

Hasil Uji Multikolinearitas

\begin{tabular}{|c|c|c|c|c|c|}
\hline Variable & Tolerance & Syarat & VIF & Syarat & Keputusan \\
\hline $\begin{array}{l}\text { Kebijkan } \\
\text { Dividen }\end{array}$ & 0,819 & $>0,1$ & 1,221 & $<10$ & $\begin{array}{c}\text { Tidak terjadi } \\
\text { multikolinieritas }\end{array}$ \\
\hline Likuiditas & 0,629 & $>0,1$ & 1,589 & $<10$ & $\begin{array}{c}\text { Tidak terjadi } \\
\text { multikolinieritas }\end{array}$ \\
\hline Tangibility & 0,642 & $>0,1$ & 1,558 & $<10$ & $\begin{array}{c}\text { Tidak terjadi } \\
\text { multikolinieritas }\end{array}$ \\
\hline Asset Turnover & 0,878 & $>0,1$ & 1,139 & $<10$ & $\begin{array}{c}\text { Tidak terjadi } \\
\text { multikolinieritas }\end{array}$ \\
\hline $\begin{array}{l}\text { Company } \\
\text { Growth }\end{array}$ & 0,970 & $>0,1$ & 1,031 & $<10$ & $\begin{array}{c}\text { Tidak terjadi } \\
\text { multikolinieritas }\end{array}$ \\
\hline
\end{tabular}

Sumber: lampiran

Berdasarkan hasil uji multikolinearitas pada tabel 2 dapat diketahui bahwa variabel kebijakan dividen, likuiditas, tangibility, asset turnover, dan company growth memiliki nilai tolerance $>0,1$ dan nilai VIF $<10$, maka dapat disimpulkan bahwa tidak terjadi multikolinearitas dalam model regresi.

Tabel 3

Hasil Uji Heteroskedastisitas

\begin{tabular}{llll}
\hline Variabel & Sig & Standar & Keterangan \\
\hline Kebijkan Dividen &, 615 & $>0,05$ & Tidak terjadi heteroskedastisitas \\
Likuiditas &, 043 & $>0,05$ & Tidak terjadi heteroskedastisitas \\
Tangibility &, 891 & $>0,05$ & Tidak terjadi heteroskedastisitas \\
Asset Turnove &, 461 & $>0,05$ & Tidak terjadi heteroskedastisitas \\
Company Growth &, 697 & $>0,05$ & Tidak terjadi heteroskedastisitas \\
\hline
\end{tabular}

Sumber: lampiran

Berdasarkan hasil uji heteroskedastisitas pada tabel 3 menunjukan bahwa variabel kebijakan dividen, likuiditas, tangibility, asset turnover, dan company growth memiliki nilai signifikansi $>0,05$, maka dapat disimpulkan bahwa tidak terjadi heteroskedastisitas dalam model ini.

Tabel 4

Hasil Uji Autokorelasi

\begin{tabular}{lllllll}
\hline DW & Dl & Du & 4-dL & 4-dU & Kriteria & Keputusan \\
\hline 2,129 & 1,3815 & 1,7678 & 2.6185 & 2,2322 & DU < DW < 4- & $\begin{array}{l}\text { Tidak terjadi } \\
\text { autokorelasi }\end{array}$ \\
& & & & & DU &
\end{tabular}

Sumber: Lampiran

Berdasarkan uji autokorelasi pada tabel di $4 \mathrm{DW}$, nilai dL untuk $\mathrm{n}=56$ dan $\mathrm{k}=5$ yaitu sebesar 1,3815 dan nilai dU yaitu sebesar 1,7678. Nilai Durbin Watson pada tabel diatas menunjukkan angka 2,129. Sehingga $d u<d w<4-d u$, yaitu 1,7678 $<2,129<2,2322$. Berdasarkan kriteria tabel nilai uji Durbin Watson hasil ini menunjukan tidak terjadi autokorelasi.

Tabel 5

Hasil Uji Analisis Regresi Linear Berganda

\begin{tabular}{lc}
\hline Model & B \\
\hline Struktur Modal & \\
Kebijakan Dividen & 0,529 \\
Likuiditas & 0,765 \\
Tangibility & $-0,142$ \\
\hline Asset Turnover & 0,572 \\
\hline
\end{tabular}




\begin{tabular}{ll}
\hline Model & B \\
\hline Company Growth & 0,877 \\
\hline Sumber: lampiran &
\end{tabular}

Berdasarkan tabel 5 maka dapat persamaan regresi sebagai berikut :

$\mathrm{Y}=0,529+0,765-0,142+0,572+0,258+0,877+\mathrm{e}$

Persamaan regresi linear berganda yang telah terbentuk tersebut diatas mempunyai pengertian sebagai berikut:

1) Konstanta yang diperoleh sebesar 0,529 menyatakan bahwa jika semua variabel independen bernilai 1 persen, maka struktur modal akan naik sebesar 0,529 atau 52,9\%

2) Koefisien regresi variabel kebijakan dividen bernilai 0,765 . Hal ini berarti apabila variabel kebijakan dividen naik sebesar 1 persen dengan asumsi variabel yang lainnya tetap, maka diikuti kenaikan struktur modal sebesar 0,765 atau $76,5 \%$

3) Koefisien regresi variabel likuiditas bernilai $-0,142$. Hal ini berarti apabila variabel likuiditas turun sebesar 1 persen dengan asumsi variabel yang lainnya tetap, maka diikuti penurunan struktur modal sebesar - 0,142 atau 14,2\%

4) Koefisien regresi variabel tangibility bernilai 0,572 . Hal ini berarti apabila variabel tangibility naik sebesar 1 persen dengan asumsi variabel yang lainnya tetap, maka diikuti penurunan struktur modal sebesar 0,572 atau $57,2 \%$

5) Koefisien regresi variabel asset turnover bernilai 0,258 . Hal ini berarti apabila variabel likuiditas naik sebesar 1 persen dengan asumsi variabel yang lainnya tetap, maka diikuti penurunan struktur modal sebesar 0,258 atau $25,8 \%$

6) Koefisien regresi variabel company growth bernilai 0,877 . Hal ini berarti apabila variabel likuiditas naik sebesar 1 persen dengan asumsi variabel yang lainnya tetap, maka diikuti penurunan struktur modal sebesar 0,877atau $87,7 \%$

Tabel 6

Uji F Statistik

\begin{tabular}{clllll}
\hline Model & F $_{\text {hitung }}$ & F $_{\text {tabel }}$ & Sig & Syarat & Keputusan \\
\hline 1 & 9,844 & 2,557 & 0,000 & 0,05 & Simultan \\
\hline
\end{tabular}

Sumber: lampiran

Berdasarkan pada tabel 6 , diperoleh $\mathrm{F}$ hitung sebesar 9,844 > F tabel sebesar 2,557 dan signifikansi sebesar $0,000<0,05$ sehingga terlihat bahwa nilai signifikansi tersebut lebih kecil dari 0,05 . Hal ini menunjukan bahwa variabel independen signifikansi secara bersamasama berpengaruh terhadap variabel dependen.

Tabel 7

Uji Hipotesis

\begin{tabular}{|c|c|c|c|c|c|}
\hline Hipotesis & t hitung & t tabel & Sig. & Std & Keterangan \\
\hline $\begin{array}{l}\text { Kebijakan } \\
\text { Dividen }\end{array}$ & 0,862 & $-2,008$ & 0,393 & $>0,05$ & Ditolak \\
\hline Likuiditas & $-3,819$ & $-2,008$ & 0,000 & $<0,05$ & Diterima \\
\hline Tangibility & 1,215 & $-2,008$ & 0,230 & $>0,05$ & Ditolak \\
\hline Asset Turnover & 2,180 & $-2,008$ & 0,034 & $<0,05$ & Diterima \\
\hline $\begin{array}{l}\text { Company } \\
\text { Growth }\end{array}$ & 1,424 & $-2,008$ & 0,161 & $>0,05$ & Ditolak \\
\hline
\end{tabular}

Sumber: lampiran

Berdasarkan tabel 7 tersebut menunjukan bahwa nilai signifikan kebijakan dividen sebesar 0,393 menyatakan bahwa kebijakan dividen ditolak dengan hipotesis kebijakan dividen tidak berpengaruh terhadap struktur modal. Nilai signifikan likuiditas sebesar 0,000 menyatakan bahwa likuiditas diterima dengan hipotesis likuiditas berpengaruh terhadap struktu modal. Nilai signifikan tangibility sebesar 0,230 menyatakan bahwa tangibility ditolak dengan hipotesis tangibility tidak berpengaruh terhadap struktu modal. Nilai signifikan asset 
turnover sebesar 0,034 menyatakan bahwa aset turnover diterima dengan hipotesis asset turnover berpengaruh terhadap struktu modal. Nilai signifikan company growth sebesar 0,161 menyatakan bahwa company growth ditolak dengan hipotesis Company growth tidak berpengaruh terhadap struktu modal.

\section{Tabel 8}

\section{Uji Koefisien Determinasi}

\begin{tabular}{ll}
\hline Adjusted R Square & Kesimpulan \\
\hline 0,446 & Berpengaruh sebesar 44,6\% \\
\hline Sumber: lampiran &
\end{tabular}

Berdasarkan tabel 8 hasil dari pengujian koefisien determinasi (Uji R) pada tabel 4.9 menunjukan bahwa adjusted $r$ square sebesar 0,446. Hal ini dapat diartikan bahwa 44,6\% variasi variabel dependen yaitu struktur modal dapat dijelaskan oleh variabel independen yaitu kebijakan dividen, likuiditas, tangibility, asset turnover, dan company growth, sedangkan sisanya yaitu $55,4 \%$ dijelaskan atau dipengaruhi oleh faktor-faktor lain diluar penelitian ini.

Berdasarkan hasil diatas maka pembahasan pada penelitian ini sebagai berikut:

Berdasarkan hasil pengujian uji t diperoleh t hitung untuk variabel kebijakan dividen 0,862 yang artinya $t$ hitung $<\mathrm{t}$ tabel $(0,862<2,008)$ dan nilai signifikansi sebesar 0,393 yang artinya nilai signifikansi $>0,05(0,393>0,05)$ maka ditarik kesimpulan bahwa kebijakan dividen tidak berpengaruh terhadap strukur modal. Hal ini karena perusahaan telah mencapai tahap dewasa (mature), sehingga aliran kas perusahaan relatif lebih stabil dan cenderung menggunakan dana internalnya terlebih dahulu untuk membiayai investasinya sebelum menggunakan pembiayaan eksternal melalui hutang. Maka, perusahaan subs sector barang konsumsi yang terdaftar di Bursa efek indonesia yang mempunyai nilai dividen tinggi berarti perusahaan tersebut memiliki jumlah saham yang tinggi dan otomatis telah meminimalisirkan hutang pada pihak eksternal hal ini disebabkan oleh tingginya keuntungan yang diperoleh perusahaan dari pihak investor dengan adanya kegiatan investasi, sehingga perusahaan lebih mengutamakan menggunakan dana yang diperoleh dari keuntungan menginvestasikan sahamnya. Sehingga kebijakan dividen tidak berpengaruh terhadap struktur modal. Hasil penelitian ini didukung oleh penlitian terdahalu yang dilakukan oleh Sivathaasan (2013),Wiajaya (2014) dan Lestari et al (2015) yang menyatakan bahwa kebijakan dividen berpengaruh terhadap struktur modal.

Berdasarkan hasil pengujian uji t diperoleh t hitung untuk variabel likuiditas $-3,819$ yang artinya t hitung $>\mathrm{t}$ tabel $(-3,819>2,008)$ dan nilai signifikansi sebesar 0,000 yang artinya nilai signifikansi $<0,05(0,000<0,05)$ maka ditarik kesimpulan bahwa likuiditas berpengaruh terhadap strukur modal. Hal ini artinya semakin tinggi likuiditas perusahaan, maka semakin menurunkan struktur modal, sesuai dengan teori packing order yang mengatakan bahwa perusahaan yang memiliki tingkat likuiditas yang tinggi maka cenderung utangnya lebih rendah. Sehingga likuiditas perusahaan yang tinggi akan mengurangi penggunaan pendanaan ekstenal. Penggunaan utang jangka panjang dalam struktur modal di perusahaan-perusahaan semakin menurun seiring meningkatnya tingkat likuiditas perusahaan, hal tersebut dikarenakan perusahaan sudah mendapatkan keuntungan dari ekuitas yang lebih likuid sehigga perusahaan menggunakan modal sendiri dari pada menggunakan utang jangka panjang. Perusahaan sub sector barang konsumsi yang terdaftar di bursa efek indonesia memiliki jumlah asset yang tinggi sehingga perusahaan ini menghasilkan profit yang tinggi sehingga dapat mencukupi kebutuhan perusahaan tersebut. Hasil penelitian ini didukung oleh penlitian terdahalu yang dilakukan oleh Sheikh, et al (2011), Pattweengko (2014), Ananto (2015) yang menyatakan likuiditas berpengaruh terhadap struktur modal.

Berdasarkan hasil pengujian uji $t$ diperoleh $t$ hitung untuk variabel tangibility 1,215 yang artinya $t$ hitung $>t$ tabel $(1,215<2,008)$ dan nilai signifikansi sebesar 0,230 yang artinya nilai signifikansi $<0,05(0,230>0,05)$ maka ditarik kesimpulan bahwa tangibility tidak berpengaruh terhadap strukur modal. Hasil ini artinya tangibility mengalami kenaikan 
maupun penurunan tidak mempengaruhi struktur modal, perusahaan yang memiliki tangibility tinggi secara otomatis perusahaan juga memiliki asset yang berjumlah tinggi, hal tersebut berdampak pada laba sebuah perusahaan yang juga akan semakin meningkat, perusahaan sub sector barang konsumsi yang terdaftar di Bursa Efek Indonesia yang memiliki jumlah asset yang memadai sehingga perusahaan ini mampu mencukupi kebutuhan dengan menggunakan dana internal saja. sehingga perusahaan akan lebih mengutamakan penggunaan dana dari internal daripada dan eksternal, sehingga tangibility tidak berpengaruh terhadap struktur modal. Hasil penelitian ini didukung oleh penlitian terdahalu yang dilakukan oleh Rafiq et al, Yunita dan Aji (2018) yang menyatakan tangibility tidak berpengaruh terhadap struktur modal.

Berdasarkan hasil pengujian uji t diperoleh $t$ hitung untuk variabel asset turnover 2,676 yang artinya thitung $>\mathrm{t}$ tabel $(2,696>2,008)$ dan nilai signifikansi sebesar 0,034 yang artinya nilai signifikansi $<0,05(0,034<0,05)$ maka ditarik kesimpulan bahwa asset turnover berpengaruh terhadap strukur modal. Hal ini karena semakin besar penjualan dari aset maka struktur modal akan semakin meningkat, perusahaan yang memiliki asset turnover tinggi menandakan bahwa perusahaan memiliki kemampuan yang sangat baik dalam segi penjualan, sehingga akan menambah tingkat keuntungan pada perusahaan yang berdampak pada peningkatan struktur modal, sehingga pengelolaan seluruh aktiva pada perusahaan semakin efektif. Perusahaan sub sector barang konsumsi yang terdaftar di bursa efek indonesia yang memiliki penjualan yang tinggi akan meningkatkan laba perusahaan, perusahaan yang memiliki laba yang tinggi akan berusaha meningkatkan jumlah assetnya, perusahaan yang ingin meningkatkan jumlah assetnya otomatis membutuhkan dana yang besar maka dari itu perusahaan akan menggunakan dana eksternal untuk mencukupi kebutuhannya dalam peningkatan jumlah asset. Sehingga asset turnover berpengaruh terhadap struktur modal. Hal ini sejalan dengan Hasil penelitian ini didukung oleh penlitian terdahalu yang dilakukan oleh Wardhana (2016), Astuty (2018) dan Utami (2016) yang menyatakan asset turnover berpengaruh terhadap sruktur modal.

Berdasarkan hasil pengujian uji t diperoleh t hitung untuk variabel Company growth 1,424 yang artinya $t$ hitung $>\mathrm{t}$ tabel $(1,424<2,008)$ dan nilai signifikansi sebesar 0,161 yang artinya nilai signifikansi $>0,05(0,161>0,05)$ maka ditarik kesimpulan bahwa company growth tidak berpengaruh terhadap strukur modal. Hal ini karena pertumbuhan perusahaan mengalami kenaikan yang kecil dari tahun sebelumnya. Semakin besar pertumbuhan perusahaan, maka struktur modal akan semakin rendah, besarnya pertumbuhan perusahaan di akibatkan karena kemampuan suatu perusahaan dalam melakukan penjualan sesuai dengan yang diharapkan oleh perusahaan. Dengan penjualan, perusahaan akan mempunyai dana yang lebih untuk memenuhi kebutuhan perusahaan, sehingga semakin besar pertumbuhan perusahaan maka struktur modal suatu perusahaan akan semakin rendah. Perusahaan sub sector barang konsumsi yang memiliki pertumbuhan perusahaan yang tinggi dapat memenuhi kebutuhan perusahaan dengan menggunakan dana internal hasil dari laba penjualan dan cenderung tidak menggunakan dana eksternal. Sehigga Company Growth tidak berpengaruh terhadap struktur modal. Penelitian ini sejalan dengan Marfuah (2017) dan Mulyani (2017) yang menyatakan company growth tidak berpengaruh terhadap struktur modal.

\section{KESIMPULAN}

Penelitian ini bertujuan untuk menguji pengaruh kebijakan dividen, likuiditas, tangibility, asset turnover dan comapny growth terhadap struktur modal.penelitian ini menggunakan sampel 56 perusahaan sektor industri barang konsumsi yang terdaftar di BEI periode tahun 2015-2018. Penentuan sampel ini menggunakan purposive sampling dengan kriteria dan ketentuan tertentu. Berdsarkan hasil analisis menunjukan bahwa variabel kebijakan dividen tidak berpengaruh terhadap struktur modal, hasil penelitian ini didukung oleh, (Wijaya, 2014) dan (Lestari, 2015) yang menyatakan bahwa kebijakan dividen tidak berpengaruh terhadap struktur modal. Berdasarkan hasil penelitian menunjukan bahwa 
likuiditas berpengaruh terhadap struktur modal, hasil penelitian ini didukung oleh (Sheikh, Nadeem, \& Zongjun, 2011), (Pattweekongka, 2014), (Ananto, 2015) yang menyatakan bahwa likuiditas berpengaruh terhadap struktur modal. Berdasarkan hasil penelitian menunjukan bahwa likuiditas berpengaruh terhadap struktur modal, hasil penelitian ini didukung oleh peneliti Rafiq (2011), (Yunita S. d., 2018) menyatakan bahwa tangibility tidak berpengaruh terhadap struktur modal. Berdasarkan hasil penelitian menunjukan bahwa asset turnover berpengaruh terhadap struktur modal, hasil penelitian ini didukung oleh peneliti ( Wardhana, 2016), Wiawatankantang dan Santi ( 2017) dan (Utami, Pratiwi, \& Misbahul, 2018) yang menyatakan bahwa asset turnover berpengaruh terhadap struktur modal. Berdasarkan hasil penelitian menunjukan bahwa company growth tidak berpengaruh terhadap struktur modal, hasil penelitian ini didukung oleh peneliti (Marfuah, 2017) dan (Mulyani, 2017) yang menyatakan bahwa company growth tidak berpengaruh terhadap struktur modal.

Keterbatasan penelitian ini adalah Populasi pada penelitian ini terbatas pada perusahaan sektor industri barang konsumsi yang menggunakan data dengan periode 4 tahun berturut-turut yaitu pada tahun 2015-2018 yang menyebabkan sampel yang digunakan terbatas dan komponen variabel independen yang digunakan dalam penelitian ini hanya 5 variabel yaitu, kebijakan dividen, likuiditas, tangibility, asset turnover, dan company growth sehingga $55,4 \%$ faktor lain yang menjelaskan struktur modal belum bisa diketahui dalam penelitian ini.

Brerdasarkan kesimpulan dan keterbatasan pada penelitian ini maka saran bagi peneliti selanjutnya diharapkan dapat menambah populasi tidak hanya pada sektor industri barang konsumsi dan masa periode yang lebih lama agar memperkuat hasil penelitian dan bagi peneliti selanjutnya diharapkan dapat menambah variabel - variabel lain agar dapat memperkuat hasil penelitian

\section{DAFTAR PUSTAKA}

Ananto. (2015). Pengaruh Profitabilitas, Kepemilikan Institusional, Growth Opportunity Dan Likuiditas Terhadap Struktur Modal Pada Perusahaan Manufaktur Yang Terdaftar di Bursa Efek Indonesia.

Ardhianto, R. (2014). Pengaruh kebijakan Dividen, Resiko Bisnis, Kontrol Kepemilikan, Cash Holding dan Non DEbt Tax Shield Terhadap Struktur Moodal Pada Perusahaan Manufaktur yang Terdaftar di Bursa Efek Indonesia. JOM FEKON Vol. 1 No. 2 Oktober 2014.

Arini, F. (2013). Pengaruh Likuiditas, Ukuran Perusahaan, Struktur Aktiva, Profitabilitas, dan Pertumbuhan Penjualan Terhadap Struktur Modal (Studi Pada Perusahaan Pertambangan Yang Terdaftar di Bursa Efek Indonesia). Artikel Brawijaya Malang .

Astuti, E. (2018). Determinant Capital Structure Of Banking Company in Indonesia. Accounting Departement, Unversitas PGRI mMadiun, Vol22 No. 12018.

Budiarso, N. (2014). Struktur Modal dan Kinerja Perusahaan (Studi Pada Perusahaan yang Terdaftar di Bursa Efek Indonesia Periode 2011-2012). Jurnal Riset Akuntansi Dan Auditing "Goodwill" 5 (1):30-38.

Dewiningrat, A. I., \& Mustanda, I. K. (2018). Pengaruh Likuiditas, Profitabilitas, Pertumnuhan Penjualan, Dan Struktur Asset Terhadap Struktur Modal. E-Jurnal Manajemen Unud, Vol. 7,3471-3501.

Eviana, A. D. (2015). Pengaruh Struktur Aktiva, Pertumbuhan Penjualan, Dividend Payout Ratio, Likuiditas dan Profitabilitas Terhadap Struktur Modal. Jurnal Akuntansi dan Sistem Teknologi Informasi, 11 (2):194-202.

Fahmi, I. (2012). Analisis Laporan Keuangan . Bandung: Alfabeta. 
Ghifaari, S. B. (2018). Pengaruh Pertumbuhan Penjualan, Tangibility, Assets Turonver dan Profitabilitas Terhadap Struktur Modal Perusahaan Sub Sektor Transportasi yang Terdaftar di Bursa Efek Indonesia (BEI). Jurnal IImu Ekonomi, Manajemen, dan Akuntansi. Volume 7 No. 1 Maret 2018; ISSN: 230-4747.

Gunawan, A. (2011). Pengaruh Profitabilitas dan Perputaran Aktiva Terhadap Struktur Modal. Jurnal Manajemen \& Bisnis, 11 (01), 12-24 .

Hani, S. (2015). Teknin Analisa Laporan Keuangan. Medan:UMSU PRESS.

Houston, B. d. (2011). Dasar- dasar Manajemen Keuangan, Buku 2 Edisi 11. jakarta: Salemba Empat.

Kasmir. (2015). Analisis Laporan Keuangan ,Edisi kesatu cetakan kedelapan. Jakarta: PT Raja Grafindo Persada.

Khairy, M. d. (2016). Faktor- Faktor yang Mempengaruhi Struktur Modal ( Studi kasus pada perusahaan Manufaktur yang Terdaftar di Bursa Efek Indonesia periode 2011-2014). Jurnal Wawasan Manajemen. Vol 4 No.2.

Lestari, S. A. (2015). Pengaruh Kepemilikan saham dan Rasio Keuangan Terhadap Struktur Modal. Jurnal IImu dan Riset Akuntansi. Vol. 4, No. 3.

Lina, J. d. (2010). Faktor-Faktor yang Mempengaruhi Struktur Modal. STIE Trisakti. Jurnal Bisnis dan Akuntansi. Vol 12, No.2 Agustus 2010, HIm. 81-96.

Luh Putu Widayanti, N. T. (2016). Pengaruh Profitablitas, Tingkat Pertumbuhan Perusahaan, Likuiditas, dan Pajak Terhadap Struktur Modal. E-jurnal Manajemen Unud, Vol. 5, No 6:3761-3793.

Marfuah, S. A. (2017). Pengaruh Firm Size, Asset Growth, Profitabilitas dan Pertumbuhan Penjualan Terhadap Struktur Modal Cosmetics and Hoesheld di Bursa Efek Indonesia. Jurnal Akuntansi .

Meidiyustianti, R. (2016). Pengaruh Ukuran Perusahaan Pertumbuhan Penjualan, Total Asset Turnover dan Likuiditas Terhadap Struktur Modal pada Perusahaan Manufaktur Sektor Industri Barang Konsumsi Yang Terdaftar di Bursa Efek Indonesia Tahun 20102014. Jurnal Akuntansi dan Keuangan, 5 (2),41-59.

Mohammad, N. F. (2015). Pengaruh Kebijakan Dividen, Profitabilitas dan Pertumbuhan Perusahaan Terhadap Struktur Modal (Strudi Pada Sektor Mining yang Terdaftar di Bursa Efek Indonesia Periode 2011-2013) . Jurnal Administrasi Bisnis,24 (1):1-10 .

Mulyani, H. S. (2017). Analisis Struktur Modal Berdasarkan Growth Opportunity, Profitabilitas, Effektive Tax Rate dan Asset Tangibility (Studi Pada Perusahaan Food and Beverage yang Terdaftar di Bursa Efek Indonesia Tahun 2011-2015. Jurnal IImiah Manajemen dan Akuntansi. Vol. 4 No.2. ISSN:2536-3923 .

Nainggolon, M. V. (2017). Pengaruh Kebijakan Dividen, Profitabilitas, Ukuran Perusahaan, Resiko Bisnis, Cash Holding, Kontrol kepemilikan, dan Debt Tax Shield Terhadap Struktur Modal Pada Perusahaan Manufaktur yang Terdaftar di Bursa Efek Indonesia (Periode 2011-2014). JOM Fekom Vol.4, No 1.

Nurmadi, R. (2013). Analisis Faktor-Faktor yang Mempengaruhi Struktur Modal Perusahaan Manufaktur. Jurnal Keuangan dan Bisni, 5(2) , 170-178.

Pattweekongka, s. a. (2014). Determinans Of capital Structure: Evidience From Thai Lodging Companies. International Journal of Arts \& Science, 7(4):45-52 .

Pratheepan, T. \&. (2016). The Determinants of Capital Structure: Evidence From Selected Listed Companies in Sri Lanka. Journal of Economics and Finance, Vol. 8, No. 2 . 
Primantara, A. A. (2016). Pengaruh Likuiditas, Profitabilitas, Resiko Bisnis, Ukuran Perusahaan dan Pajak Terhadap Struktur Modal. E-Jurnal Manajemen Unud, 5(5),2696-2726 .

Puspitasari, O. I. (2016). Pengaruh Profitability, Tangible, Leverage, Corporate Tax Dan Inflation Rate Terhadap Struktur Modal Pada Perusahaan Manufaktur Yang Listing di Bursa Efek Indonesia. Journal Of Accounting .

Putra, D. d. (2012). Pengaruh Profitabilitas, Likuiditas, Ukuran, Pertumbuhan Terhadap Struktur Modal Industri Otomotif di Bursa Efek Indonesia. Artikel. Universitas Udayana Bali .

Ramadhan, M. F. (2010). Faktor-faktor yang Mempengaruhi Sruktur Modal Pada Industri Manufaktur di Bursa Efek Indonesia. Jurnal Bisnis dan Auntansi, Vol 12, No.2, Agustus 2010.

Sabir, M. d. (2012). Determinants of capital Structure - A study of oil and gas Sector of Pakistan. Interdisciplinari Journal Of Contemporary research in busines. Vol 3 No.10.

Sahabuddin, Z. A. (2017). Asset Structure Impact on Capital Structure of Capital Market Listed in Indonesia and Malaysia. jurnal keuangan dan perbankan. Vol. 21 No.3 .

Setiawan, d. (2016). Pengaruh Firm Size, Growth Opportunity, Profitability, Business Risk, Effective Tax Rate, Asset Tangibility, Firm Age, dan Likuidity Terhadap Struktur Modal Perusahaan ( Studi Pada Perusahaan Sektor Property dan Real estate yang Terdaftar di BEI Tahun 2009-2014. Jurnal Administrasi Bisnis (JAB), Vol.31 No 1.

Sheikh, A., Nadeem, \& Zongjun. (2011). Determinans Of Capital Structure : An EmpricallStudy OfFirms In Manufacturing Industry Of Pakistan. Managerial Finance, Volume 37 Nomor 2 hal 117.

Sivathaasan, S. d. (2013). Factors Determining Capital Structure : A case Study of Listed Companies In Sri Lanka. Research Journal Of Finance and Accounting. Vol. 4, No.6 .

Sugiyono. (2010). Metode Penelitian Pendidikan Pendekata Kuantitatif, Kualitatif, dan R \& d. Bandung:Alfabeta

Syamsudin, L. (2009). Manajemen Keuangan Perusahaan. Jakarta: Rajawali Press.

Triani, A. W. (2014). Pengaruh Arus Kas Bebas, Kebijakan Dividen, Dan Ukuran Perusahaan Terhadap Struktur Modal. Jurnal IImu Manajemen, Vol. 2, No 4.

Utami, S. B., Pratiwi, D., \& Misbahul, S. (2018). Pengaruh Pertumbuhan Penjualan, Tangibility, Assets Turonver dan Profitabilitas Terhadap Struktur Modal Perusahaan Sub Sektor Transportasi yang Terdaftar di Bursa Efek Indonesia (BEI). Jurnal IImu Ekonomi, Manajemen, dan Akuntansi. Volume 7 No.1 Maret 2018; ISSN: 230-4747.

Widayanti. (2016). Pengaruh Profitabilitas, Tingkat Pertumbuhan Perusahaan, Likuiditas, dan pajak terhadap Struktur Modal pada Sektor Pariwisata. E-Jurnal Manajemen Unud. Vol. 5 No. 6. ISSN:2302-8912.

Wijaya, C. R. (2014). Pengaruh Struktur Aktiva, Profitabilitas, Pertumbuhan Penjualan, Kebijakan Dividen dan Resiko Bosnis Terhadap Struktur Modal pada Perusahaan Food and Beverage yang Terdaftar di BEl periode 2010-2012. JOM FEKON, 1 (2):115 .

Yeni, P. A. (2015). Pengaruh Profitabilitas, Asset Tangibility, Size, Growth Terhadap Struktur Modal Pada Perusahaan Manufaktur yang Terdaftar di Bursa Efek Indonesia Periode 2011-2013. Jurnal IImiah Universitas Surabaya .

Yunita, S. d. (2018). Pengaruh Likuiditas, Tangibility, Growth Opportunity, Resiko Bisnis dan Ukuran Perusahaan Terhadap Struktur Modal. Jurnal IImu Manajemrn. Vol 6. No.4 
Oikos: Jurnal Kajian Pendidikan Ekonomi dan IImu Ekonomi, ISSN Online: 2549-2284

Volume IV Nomor 1, Januari 2020

Yunita, S., \& Aji, T. S. (2018). Pengaruh Likuiditas, Tangibility, Growth Opportunity, Risiko Bisnis, dan Ukuran Perusahaan Terhadap Struktur Moodal. Jurnal IImu Manajemen, Vol. 6 No. 4 .

Yusrianti, H. (2013). "Pengaruh Tingkat Profitabilitas, Struktur Asset, dan GrowtOpportunity Terhadap Struktur Modal Pada Perusahaan Manufaktur yang Telah Go public Di Bei. Jurnal . 